\title{
Medical Malpractice and Awareness of Professional Liability Insurance among Physicians and Surgeons in Nigeria
}

\author{
Ogorchukwu Augustine ISIMOYA , Samson Ifejionu NWANKWO ${ }^{\star \star}$
}

\begin{tabular}{l}
\hline \multicolumn{1}{c}{ A R T I C L E I N F O } \\
\hline Article history: \\
Accepted July 2020 \\
Available online August 2020 \\
\hline JEL Classification \\
M31, 016 \\
Keywords: \\
Medical malpractices, Insurance \\
awareness, Professional indemnity \\
insurance
\end{tabular}

A B S T R A C T

\begin{abstract}
Although insurance is the traditional backbone of risk management of any modern country, yet only few people and organisations purchase insurance in Nigeria. The main purpose of this paper is to investigate the level of awareness and use of professional indemnity insurance (PII) by Nigerian medical doctors in contending with medical litigations. The research is domiciled in five local government areas in Lagos metropolitan city Nigeria. The research data was collected from sampled respondents of 50 resident doctors in both private and public medical institutions. The results revealed that majority of the medical doctors in the sample were unaware of PII and rarely made use of it in contending with financial liabilities. The research therefore recommends that insurance managers in Nigeria should boost insurance awareness among medical doctors through market communications and public educational programmes, to stimulate the latent need for insurance services among medical doctors in Nigeria.
\end{abstract}

(C) 2020 EAI. All rights reserved.

\section{Introduction}

The incidents of professional malpractices in service delivery have generally increased in recent times and have become a great concern to many scholars. Professionals service delivery of some Nigerian doctors, engineers and architects to mention but a few have been found to be fraught with carelessness, negligence and incompetence (Abugu \& Obalum, 2018). For instance, an engineer's use of substandard materials leading to building collapse and a medical practitioner's failure to appropriate follow up care to his/her patient after an operation (Okojie, 1995; Abugu \& Obalum, 2018) are commonplace in Nigeria. Globally, stricter consumer protection has emerged, through enactment of specific laws. However, consumers need to express their dissatisfaction or complaints before remedies can be effected (Donoghue \& Klerk, 2009). Nigerians suffer grave consequences in the hands of these careless professionals, as victims are reluctant to pursue the award of damages due to illiteracy and religious beliefs (Abugu \& Obalum, 2018). It could be reasonably assumed that medical malpractice has grown unabated in Nigeria due to consumers' poor knowledge, contributory negligence and ineffective behaviour. Second, medical doctors' ignorance of their legal liabilities coupled with the enforcement of financial protection they could obtain through professional indemnity insurance (PII) for their professional negligence may have contributed also.

While some scholars have debated the impact of systematic failures such as brain drain syndrome, obsolete equipment, industrial strikes, under funding, etc on health care provision in Nigeria (Chukwuneke, 2015; Abubakar, Basiru, Oluyemi, Abdulateef, Atolagbe, Adejoke \& Kadiri, 2018); other researchers on the other hand, stressed that continuous decline in professionalism, lackadaisical attitude of health care providers are the root cause of medical malpractice in Nigeria (Mosine, Reddy \& Karodia, 2016; BayeroJumoh \& Yahaya, 2016). However, inability of victims of medical malpractice to sue for remedies in the event of damages, injury or morbidity, traceable to the negligent act of the physicians, is rooted in ignorance and poverty (Bayero-Jimoh \& Yahaya, 2016).

Today, according to Chukwuneke (2015) the use of PII to ameliorate the financial liabilities of doctors involved in medical litigation is rudimentary in Nigeria. However, with the indispensability of medical services in a modern society and the sharp decline of professionalism in health care system (0kojie, 1995) coupled with the rights of victims to seek redress against unprofessional and negligent botched operations, physicians are expected to prepare against such legal liabilities by effecting PII (Mosime et al, 2016). Thus the main aim of this study is to investigate the level of awareness and use of PII by Nigerian medical doctors

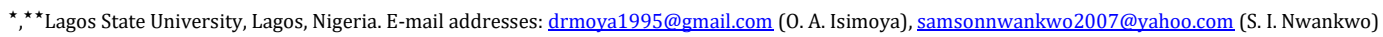


against financial and legal liabilities resulting from professional negligence in their service delivery. The remaining sections of this study are thus structured: Literature review and methodology are presented in sections two and three respectively. This is followed by results in section four and conclusions presented in section five.

\section{Literature Review}

\section{1. $\quad$ Medical Malpractice}

Medical malpractices also known as medical negligence (Mosime, Reddy \& Karodia, 2016), and is defined by the American Medical Association as a doctor's failure to employ the degree of care and skill that a different physician of the same specialty, would apply under similar circumstances (Brenner, 2010). However, while the concept of malpractice hinges on breach of duty of care, perhaps as a result of dereliction of duty or lackadaisical attitude; medical negligence, usually a legal concept, hinges on an act or omission by a medical professional that deviates from accepted medical standard of care (Groguen, 2019). This deviation could result from lack of knowledge in the practice (quack) (Pandit \& Pandit, 2009) or human error on the part of the professional. Medical negligence has also been defined as the exit from good or accepted medical care (Oginski, 2012) while Bardale (2011) stated that medical negligence amounts to lack of reasonable degree of care and skill or willful negligence displayed by a medical practitioner while treating his or her patient resulting in bodily injury, morbidity or death. Furthermore, Aimakhu (2015) defined medical malpractice as professional negligence by act or omission by a health care provider, whose services depart from acceptable standards of practice in the medical profession and cause harm to the patient.

It is generally believed that untimely death, morbidity and untold financial hardship on the victims are as a result of defective treatment, lackadaisical attitude and dereliction of duty of care on the part of medical practitioners. It is also argued that these incidents of losses would have been avoided if due diligence, skill and needed knowledge, on the part of the practitioners were applied. However, most times medical errors occurrence are traceable to system flaws and not character flaws. System flaws is due to inadequate medical facilities while character flaws result from ignorance on technical matters that any professional worth his salt should be familiar with.

Mosime et al (2016) noted that decline in the levels of professionalism among health care practitioners has been penciled down as one of the notable factors which have caused a rise in medical malpractice litigation in South Africa. Professionalism in the medical field comprised a set of rules and relationship which include integrity, compassion, altruism, continuous improvement and excellence (Mosime et al, 2016). Additionally, health care system failures such as brain drain syndrome which no doubt, have contributed to the decline in professionalism, has negatively affected the health care system due to shortage of health care providers (Abubakar, et al, 2018). Moreover, underfunding of the health system and health facilities in the country, such as inadequate compensation of health professionals and the purchase of medical modern equipment are contributory factors to medical malpractice in Nigeria. Other systematic failures include incessant industrial strikes involving doctors and allied health care providers (Hassan, 2013; Obi, 2014) leading to several avoidable deaths, complications and to mass exodus of Nigerians abroad, seeking for medical services (Adepimpe, Owolade \& Adepimpe, 2010). In health care system literature in Nigeria, dilapidated structures and obsolete medical equipment have been identified as bane to quality health care (Akinsete, 2016). Many government owned hospitals are in bad shape (Akor, 2015) as employed doctors refer their patients to private laboratory and diagnostic centres for laboratory examinations and investigation (Mekwunye, 2016).

Given the above, it is not surprising that medical tourism (for those who can afford it) and medical malpractices (a breach of professional obligation and negligence of duty) have been on the continuous increase in Nigeria. However, while Nigerians are becoming aware of their rights to sue for damages, as a result of the global rise of medical litigation, most Nigerian physicians are ill prepared for medical litigation (Aimakhu, 2015) which is the crux of this study.

\subsubsection{Professional Indemnity Insurance (PII)}

PII otherwise called professional liability insurance is not a new insurance service product, rather, it is an offshoot of public liability insurance which is also part of general liability policy. Unlike the general liability policy which responds to bodily injury and property damage of third parties, the professional liability insurance covers costs and damages for negligence misrepresentation, breach of duty of care and inaccurate advice from a professional (Wikipedia). For instance, if a software product fails to perform properly, though it may not result to bodily injury or property damage which general liability policy covers, however the financial losses incurred as a result of the mal-performance of the software may be attributed to the professional misrepresentation. Professional liability insurance would respond to losses such as providing wrong advice, misrepresentation and recommendations by the professional to the clients.

PII takes on different names depending on the profession and clime. For instance, it is known as Errors and omission insurance by IT professionals in US and with regards to health professional it is called medical malpractice insurance is South Africa (Dinnie, 2019). Other professionals like Architects, Consultants 
and Engineers styled it professional liability insurance. The coverage provided by PII include alleged failure or ill performance and its attendant financial losses arising from wrong advice or recommendation, errors and omissions in the service or product rendered to clients by the professional. Also covered is the potential cost of litigation for accusation against wrong doing on the part of the professional. However, the nature of malpractice the PII covers professional against, vary from one professional to another. In medicine for instance, failure to obtain the consent of a patient (informed or otherwise) before proceeding on any surgery or a mistake in treatment such as administration of wrong drugs for an ailment diagnosed. For an architect, specification of inappropriate building materials, alleged structural defects in a newly constructed building supervised by the architect, amount to professional malpractice. For the medical doctors, indemnity applies only on the claim arising out of bodily injury and/or death of any patient caused or alleged to have been caused by error, omission, or negligence of the medical doctor, his assistants, or team of people employed in his work place. PII apart from providing compensation awarded against the professional doctor, also contributes to mental stability of the professional while at work, such that even if some negligence is proved, the insurance company will provide the relief (Agarwal \& Agarwal, n.d.). PII protects the professional against costs and damages of lawsuits arising from alleged lapses in the performance of his/her business.

\subsubsection{Medical Malpractice and Nigerian Physicians and surgeons Awareness of Professional Indemnity Insurance}

The Nigerian public is increasingly becoming more aware and unforgiving in medical negligence and litigation due to media coverage of cases of alleged medical negligence and the right of victims to seek redress. According to Aimakhu (2015) medical malpractice which is a breach of a physician's obligation and negligence of duty by a medical practitioner has been identified as the major cause of medical litigation in Nigeria. Although most hospital management face increasing complaints regarding the facilities, there are also complaints against standards of professional competence, negligence and appropriateness of physicians' therapeutic and diagnostic methods, yet most physicians are today ill-prepared for medical litigation in Nigeria (Aimakhu, 2015). The importance of PII otherwise known as medical malpractice insurance among medical professionals cannot be overemphasized as it protects the insured physician from financial legal liability arising from medical litigation.

Despite the critical importance of PII, there is scanty empirical investigation of the extent to which medical doctors in Nigeria understand their legal liability in medical malpractice and the use of PII for such the emergencies. Thus advocacy could enhance public and individual awareness of responsibility towards risks, understanding of insurance as a risk transfer mechanism and the development of consumers knowledge and capacity, that affect consumers' positive behaviour and decisions regarding insurance matters (OECD, 2006). Unlike India's life insurance market, where customers are not only aware of various policies available, but are informed about the lapses of the policies, revival of the policies and the surrendered values (Suganya, 2017), in Nigeria, insurance awareness is at a low ebb (Akinbola \& Isaac, 2010). Hence, the customer awareness will grant knowledge not only to choose a product/service suitable, but engage the carrier and the agent to provide the right information. Awareness has been described as ability to perceive, feel and be conscious of events, objects or sensory pattern (Inegbedion, 2015). Customer awareness influences the choice people make when proposing to buy any product or service. It influences customers' expectations and explains their behaviour (Alinvi \& Babri, 2007). For instance a consumer could buy insurance service either because of higher expected probability of making a claim or becoming more risk averse (Ericson, Kircher, Spinnewijn \& Stark, 2016). Others may also buy just to satisfy regulatory requirements. The consequences of not having sufficient awareness can affect the level of insurance consumption and a missed opportunity for increase in insurance sales (Outreville, 2014). Moreover, Tomczyjk, Doligalski and Zaborek (2016) noted that a company would be better equipped if she creates adequate awareness of her products and service offering in order to attract more customers and become more competitive. The basic factors that influence the demand of any service, or product is the satisfaction the consumer derives from the use or consumption of that product or service. With regards to insurance service a consumer's satisfaction is based on the increase in financial security achieved by transferring the risk of financial loss to the insurer. With reference to increase insurance demand, some notable and contemporary researchers (Dragos, 2014; Tooth, 2015; Adeleke, Olowokudejo \& Ajemunigbohun, 2016) have noted that increase in insurance demand can be explained by four cases of logarithmic utility such as:

$>$ Changes in the level of wealth

$>$ Changes in the probability of loss

$>$ Effects of changes in loss severity

$>$ Effects of changes in insurance premium

With reference to professional indemnity insurance for medical doctors, the changes in the probability of loss and loss severity (medical litigation) are on the increase in Nigeria (Aimakhu, 2015). However, to what extent are Nigerian medical doctors adequately prepared through the use of PII for the potential financial emergencies arising from their legal liability due to professional negligence?

Sequel to the above this study seeks to test the following hypothetical statements: 
(I) There is low level of awareness of professional indemnity insurance (PII) policy among medical practitioners in Lagos metropolitan city in Nigeria.

(II) There is low patronage and use of PII as a risk management tool among medical doctors in Lagos metropolitan city in Nigeria.

\section{Research Methods}

This research work adopted a descriptive survey research design. The motivation for its use was because it provided the researcher with the characteristics of relevant aspects of the phenomenon of interests, as well as assisting in the examination of the occurrences around the sample subjects to avoid any attempt at manipulation (Asika, 2008; Sekaran \& Bougie, 2016). Additionally, survey design had been found useful because of its capacity for behavioural prediction as well as its ability to be used in gathering of identical data regarding all sample situations (Easterby-Smith, Torpe \& Jackson, 2008). A total of 50 medical facilities with a least one medical doctor each in their employ, were selected across five local government areas of Lagos state namely: Alimosho, Ojo, Agege, Amuwo Odofin and Badagry. The choices of the sampling areas are due to proximity to the researchers.

Data collection was carried out among medical practitioners via survey questionnaire to investigate their level of awareness and extent of patronage of PII policy both as a requirement of the law and the need for protection in times when patients institute legal action against them for services rendered which they consider unsatisfactory. This study employed judgemental sampling technique. This sampling technique was useful and justified because only medical doctors were sought for among personnel of the 50 selected medical facilities for this study. The statistical instrument for the study was Kolmogorov-Smirnov test.

Regarding the correctness of the survey instrument, congruent and logical types of validity were adopted. While the former validity was effected through use of the variables explained from past literature, the latter was employed through the administration of chosen instrument to selected buyers of PII policy insurance (medical professionals) and academia in the insurance and medical profession. Eventually, experts thoroughly examined this instrument and came up with suggestions and advice which assisted the researchers in designing the questionnaire for easy understanding of the respondents.

\section{Data Analysis and Results}

\section{Data Analysis using non-parametric technique: Kolmogorov-Smirnov}

Where:

$$
/ F_{0}(X)-F_{i}(X) /
$$

$\mathrm{F}_{0}(\mathrm{X}) \quad$ observed cumulative frequency distribution of a random sample $\mathrm{n}$ observation,

$\mathrm{F}_{\mathrm{i}}(\mathrm{X}) \quad \mathrm{k} / \mathrm{n}=$ (number of observations $\left.\leq \mathrm{X}\right) /$ (Total number of observations),

$\mathrm{F}_{\mathrm{i}}(\mathrm{X}) \quad$ the theoretical frequency distribution. follows:

The critical value of $\mathrm{D}$ is found from the K-S table values for one sample test or determined as

Where:

D calculated value

$\alpha \quad$ alpha

$\mathrm{N} \quad$ population size

Acceptance Criteria: If the calculated value is less than critical value accepts null hypothesis.

Rejection Criteria: If calculated value is greater than table value reject null hypothesis

Table 1: Responses to the testing of hypothesis 1

\begin{tabular}{ccc}
\hline Sealing Measurements & Responses & Percentage (\%) \\
\hline Agree & 32 & 64 \\
Indifferent & 11 & 22 \\
Not Agree & 07 & 14 \\
Total & 50 & 100 \\
\hline
\end{tabular}

Source: Computed by the authors, $n=50$ 
Table 2: Kolmogorov-Smirnov Frequency Table for Hypothesis 1

\begin{tabular}{lccc}
\hline \multicolumn{1}{c}{ Hypothesis } & Agree & Indifferent & Not Agree \\
\hline $\mathrm{F}=$ there is low level of awareness concerning professional indemnity & & & \\
insurance policy among medical practitioners in the metropolis of & 32 & 11 & 07 \\
Lagos & & & \\
$\mathrm{F}_{0}(\mathrm{X})=$ Theoretical cumulative distribution of choice Under $\mathrm{H}_{0}$ & 0.3333 & 0.6666 & 1 \\
$\mathrm{~F}_{\mathrm{i}}(\mathrm{X})=$ Cumulative distribution of observed choices & 0.6400 & 0.8600 & 1 \\
$\mid \mathrm{F}_{0}(\mathrm{X})-\mathrm{F}_{\mathrm{i}}(\mathrm{X})$ S & -0.3067 & -0.1934 & 0 \\
\hline
\end{tabular}

The result of hypothesis 1 reveals that there is low level of awareness regarding PII policy among medical practitioners in the sprawling metropolis of Lagos, Nigeria. The table 2 proves an outcome of the calculated D value of the point of greatest differences between the cumulative distributions and cumulative observed which is calculated to be 0.1923 . With the situation above, it shows clearly that the calculated D value is less than $(-0.3067)$ is less that the critical value of 0.1923 , meaning that the null hypothesis $\left(\mathrm{H}_{0}\right)$ that there is low level of awareness concerning PII policy among medical practitioners in the vast metropolis of Lagos is accepted at $\alpha=0.05$ (see Table 2). This, then, follows that the alternate hypothesis that there is high level of awareness concerning PII policy among medical practitioners in the metropolis of Lagos is rejected in accordance with participants' responses.

Table 3: Responses to the testing of hypothesis 2

\begin{tabular}{ccc}
\hline Sealing Measurements & Responses & Percentage (\%) \\
\hline Agree & 39 & 78 \\
Indifferent & 07 & 14 \\
Not Agree & 04 & 08 \\
Total & 50 & 100 \\
\hline
\end{tabular}

Table 4: Kolmogorov-Smirnov Frequency Table for Hypothesis 2

\begin{tabular}{lccc}
\hline Hypothesis & Agree & Indifferent & Not Agree \\
\hline $\mathrm{F}=$ there is low level of awareness concerning professional indemnity & & & \\
insurance policy among medical practitioners in the metropolis of & 39 & 07 & 04 \\
Lagos & & & \\
$\mathrm{F}_{0}(\mathrm{X})=$ Theoretical cumulative distribution of choice Under $\mathrm{H}_{0}$ & 0.3333 & 0.6666 & 1 \\
$\mathrm{~F}_{\mathrm{i}}(\mathrm{X})=$ Cumulative distribution of observed choices & 0.7800 & 0.9200 & 1 \\
$\mathrm{~F}_{0}(\mathrm{X})-\mathrm{F}_{\mathrm{i}}(\mathrm{X})$ & -0.4467 & -0.2534 & 0 \\
\hline
\end{tabular}

Source: Computed by the authors

The result of hypothesis 2 reveals that there is low extent of patronage concerning PII policy a mong medical practitioners in the metropolis of Lagos. The table 4 above proves an outcome of the calculated $\mathrm{D}$ value is less than of the point of greatest difference between the cumulative distributions and cumulative observed which is calculated to be 0.1923 . With the situation above, it shows clearly that the calculated D value $(-0.4467)$ is less than the critical value of 0.1923 , meaning that the null hypothesis $\left(\mathrm{H}_{0}\right)$ that there is low patronage of PII policy among medical practitioners in the sprawling metropolis of Lagos is accepted at $\alpha=$ 0.05 (see Table 2). Thus, it follows that the alternate hypothesis that there is high extent of patronage concerning PII policy among medical practitioners in the vast metropolis of Lagos is rejected in accordance with participants' responses.

\section{Discussion}

The fundamental aim of this study was to investigate the level of awareness and the use of professional indemnity insurance (PII) by Nigerian medical doctors in contending with medical litigation arising from the professional negligence. From the data used in the analysis of this study, the two nullhypotheses which stated that there are low awareness and patronage and use of PII respectively, among medical doctors in Nigeria were supported. Tables 2 and 4 present the results of Kolmogorov-Smirnov test. Specifically, table 2, clearly shows that calculated D value i.e -0.3067 which is less than the critical value of 0.1923 (found in K-S table values) implying that the first null hypothesis which states that there is low level of awareness of PII among medical doctors in Lagos metropolitan city is supported at $\alpha=0.05$. Similarly, table 4 reveals that the calculated $D$ value is -0.4467 which is also less than the critical value of 0.1923 implying that the $2^{\text {nd }}$ null hypothesis which states that there is no significant patronage of PII among the medical doctors in Lagos metropolitan city is also support at $\alpha=0.05$. These findings are consistent with previous studies report. For instance, in an empirical research, Adewole, Dairo and Bolarinwa (2016) in Kwara State Nigeria, found that majority of their respondents (78.9\%) were aware of National Health Insurance Scheme (NHIS) but only 
$13.5 \%$ of the respondents paid for health services through NHIS Scheme. Other researchers such as Okechukwu (2016) and Ebitu, Ibok and Mbum (2012) reported that insurance patronage in Nigeria leaves much to be desired. Specifically, Okechukwu (2016) noted that motorists in Nigeria seldom buy genuine motor insurance policy (which is compulsory) and small scale entrepreneurs in our marketplaces are not aware of the significance of insurance in risk management, despite the too many market disasters in several states in the country. To buttress the above, Ebitu, Ibok and Mbum (2012) earlier stated that insurance remains the least purchased financial service in Nigeria; as less that $10 \%$ of Nigerians have insurance policy of any sort.

In insurance market survey report PWC (2015) noted that despite the disruptive social, political, economic, legal/regulatory, environmental and technological changes shaping strategic issues for industrial and commercial companies worldwide, insurance market in Nigeria is in development. Indeed, patronage of insurance services is limited to the elite and formally employed sector persons. Although third party motor vehicle insurance is compulsory coupled with other compulsory insurances such as group life policy (for employees who are under compulsory retirement schemes), health care, PII, to mention but a few, less than $1 \%$ adults have an insurance policy in Nigeria (Cenfri, 2018). This report is in line with Okechukwu's (2016) observation that insurance, though the backbone of risk management system of any country, yet the use of insurance as risk management tool in Nigeria is unimpressive. The implication of the above research reports and the findings of this current research is that insurance management in Nigeria need to boost insurance awareness through effective market communications, sales promotion and education of the potential insured on the importance of managing risk exposures through scientifically time-tested insurance services than the current informal and unscientific means of risk management tools. The report of the research by Adewole, Dairo and Bolarinwa (2016) which stated that only 13.5\% of the sampled respondents from among formal sector employees in Kwara State paid for their health services through NHIS leaves much to be desired. Using the above as a proxy to gauge the extent health insurance coverage, the lot of the unorganized informal employees that constitute $45 \%$ of the Nigerian population (Cenfri, 2018) is better imagined. Thus insurance market communications should be geared towards the building up of insurance awareness as favourable brand attitude and image cannot be formed without awareness (Macdonald \& Sharp, 2003). Consequently, this study recommends the following:

I. That National insurers association (NIA) should through her marketing communication activities, such as sales promotions, distribution of handbills, billboards, paid advertisement in the television and newspapers, public insurance education through seminars, continually create awareness on the use of PII as an efficient risk management tool for alleged professional negligence.

II. NIA should collaborate with the Nigerian Medical Association the regulatory body of registered doctors in Nigeria, to enforce the adoption of health care's PII by practicing doctors, as provided for in National health insurance scheme (NHIS) act of 1999.

III. NIA should also collaborate with Nigerian law enforcement agencies to ensure that all medical facilities private hospitals and clinics, display the PII policy covering their medical practitioners and institutions.

IV. That NIA should through organizing public seminars educate Nigeria professionals (medical doctors, architects, accountants, lawyers, etc, of the use PII as a time-tested scientific risk management tool and reliable financial instrument which provides protection from alleged embarrassing professional negligence litigation costs.

\section{Conclusion}

Medical malpractice and negligence are rife in Nigeria because of chain of reactions. Ignorance of the rights of victims to institute civil proceedings against medical practitioners for a perceived negligence, is aided by socio-economic factors and cultural notions coupled with decline in professionalism and indifferent attitude of health care providers towards their patients wellbeing. This study finding revealed two significant facts that Nigerian medical doctors may not be aware of their legal liabilities and thus for alleged medical negligence, there is low patronage of PII among them. Few purchases by the healthcare provider are perhaps only to meet statutory requirements. Although medical litigation is still rudimentary in Nigeria, with media coverage of malpractice incidents which make mountains out of molehills, even when they know that physicians and surgeons are infallible, imply that Nigerian medical doctors are not immuned to legal liabilities for their perceived negligence. Based on its findings, this study recommends that various marketing promotion activities should be geared to build up awareness on the usefulness of PII in protecting the professionals from financial embarrassment and mental instability arising from legal suits against their alleged negligence in practice.

\section{Limitations of the Study}

As with the majority of social studies research, the design of this study is subject to some limitations which possibly would have influenced the results of the study. Two notable limitations are the choice of the location of study and the size of the sampled respondents. The study is not only domiciled in Lagos State, out of 36 states in Nigeria, but also only 5 local government areas is selected out of 20 local governments in Lagos 
State. Second, the sample size of 50 medical doctors from the 50 selected medical institutions was judgementally selected out of unknown population of medical facilities in Lagos state. No doubt, these may affect the generalisability of results of the study. Additionally, cross-sectional research design and data collection method through the use of questionnaire (quantitative method) have weaknesses in that the questionnaire can fall into wrong hands and therefore may not be completed with candour. Also non-use of qualitative method of data collection deprives us the details of the situation in understanding the consumers (doctors) behaviour. Future researchers could address these shortcomings for more robust findings.

\section{References}

1. Abubakar, M., Basiru, S., Oluyemi, J., Abdulateef, R. \& Atolagbe, E. 2018. Medical tourism in Nigeria: Challenges and remedies to health care system development. International Journal of Development and Management Review, INJODEMAR 13(1), 223-238

2. Abugu, U. \& Obalum, D.C. 2018. An agenda for improving legal claims for medical malpractice in Nigeria. Asian Social Sciences, 14(5), 118-125. doi:10.5539/ass.v14n5118

3. Adebimpe, W.O., Owolade, O.A. \& Adebimpe, M.A. 2010. Health worker's perception of the use of strikes as a tool dispute resolution in Lagos State, Niger. Journal of Social Science Public Policy, 2, 19-23

4. Adeleke, I., Olowokudejo, F.F. \& Ajemunigbohun, S.S. 2016. Hazard perception and demand for insurance among selected motor cyclists in Lagos, Nigeria. The South East Asian Journal of Management, 10(2), 121-140

5. Adewole, D.A., Dairo, M.D. \& Bolarinwa, O.A. 2016. Awareness and coverage of the National Health Insurance Scheme among formal sector workers in Ilorin, Nigeria. African Journal of Biomedical Research 19(1), 1-10

6. Agarwal, S. \& Agarwal, S.S. n.d. professional indemnity insurance vis-à-vis medical professionals. Journal of Indian Academic of Forensic Medicine 31(1), 73-76

7. Aimakhu, C.0. 2015. An insight into medical malpractice and litigation tropical. Journal of Obstetrics \& Gynaecology, 32(1), 150-154

8. Akinbola, O.E. \& Isaac, L.T. 2010. Ethical issue: A problem in Nigeria insurance companies. School of Management, Blekinge Institute of Technology, Sweden

9. Akinsete, E. 2016. PPPs: The antidote to Nigeria's health care infrastructure deficit. Retrieved from http://www.lexology.com/library/detail.aspx?g=9d3ea77f_78ce_48d0_ad70_f9dbe999779a

10. Akor, 0. 2015. Nigerian health sector: Challenges new ministers should address. Retrieved at http://www.dailytrust.com.ng/news/health/nigerian_health_sector_challenges_new_ministers_should_address/123157.html on $4 / 10 / 2016$

11. Alinvi, F. \& Babri, M. 2007. Customer preferences of insurance services: How could insurance companies enhance their ability of meeting the constant changes in customer preferences in an increasingly competitive environment? Bachelor's thesis International Business programme.

12. Asika, N. 2008. Research methodology in behavioural sciences. Lagos-Nigeria: Longman Nigle Plc

13. Bardale, R. 2011. Principles of forensic medicine and toxicology. New Delhi: Jaypee Brothers Medical Publishers.

14. Bayero-Jimoh, M., Yahaya, J., Mutiat, A.L. \& Lukman, L. 2016. Physicians and wrong diagnosis of patients: An assessment of legal duties and liabilities in Nigeria. Retrieved from https://www.ajol.info $>$ naujil $>$ article $>$ do........

15. Brenner, I.R. 2010. How to survive a medical malpractice lawsuit: The physician's roadmap for success. West Sussex: John Wiley \& Sons

16. Cenfri (2018). The role of insurance in inclusive growth Nigeria diagnostic. The World Bank.

17. Chukwuneke, F.N. 2015. Medical incidents in developing countries: A few case studies from Nigeria. Nigerian Journal of Clinical Practice, (Online) 18; 20-24 Retrieved from http://www.njcponline.com/text.asp?2015/18/7/20/170821 doi:10.4103/11193077.170821

18. Dinnie, D. 2019. Understanding medical malpractice insurance in South Africa natmed medical defence, www.natmed.mobi

19. Donoghue, S. \& De Klerk, M. 2009. The right to be heard and to be understood: A conceptual framework for consumer protection in emerging economies. International Journal of Consumer Studies, 33(4), 456-467.

20. Dragos, S.L. 2014. Life and non life insurance demand: The different effects of influence factors in emerging countries from Europe and Aisa. Economic Research-Ekonomiska Istrazivan, 27(1), 169-180

21. Eaterby-Smith, M., Thorpe, R. \& Jackson, P.R. 2008. Management research (3 ${ }^{\text {rd }}$ edition), London: Sage

22. Ebitu, E.T., Ibok, N.I. \& Mbum, P.A. 2012. Factors affecting insurance consumption in Akwa Ibom State, Nigeria. Journal of Research in International Business and Management, 2(12), 323-328.

23. Ericson, K.M., Kircher, P., Spinnewjin, J. \& Starc A. 2016. Inferring risk perception and preferences using choice from insurance means: Theory and evidence. Retrieved from: https://pkircher/papers/manuscriptEKs5.pdf

24. Groguen, D. 2019. Medical negligence: The law explained (online) Retrieved from http://www.allaw.com/articles/nolo/medical_malpractice/negligence.html

25. Hassan, J. 2013. JOHESU strike: Issues, resolution and lessons. Daily independent (online) Retrieved at http://www.dailyindependentnig.com/2013/09/johesu_strike_issues_resolutions_and_lessons/on 2/10/2016

26. Inegbedion, U.E. 2015. Awareness and utilization of National health insurance scheme in Edo State Nigeria. Thesis submitted to the department of geography, Ahmadu Bello University Zaria, Nigeria.

27. Macdonald, E. \& Sharp, B. 2003. Management perceptions of the importance of brand awareness as an indication of advertising effectiveness. Marketing Bulletin, 14(2), 1-11

28. Mekwunye, E. 2016. The death camps called government hospitals in Nigeria! Read the story how Ekene lost is dad. Retrieved at https://www.bellanaija.com/2016/06/the_death_camps_called_governmenthospitals_in_nigeria_read_story_of_how_ekene_lost_his_dad / on $6 / 10 / 2016$

29. Mosime, J.S., Reddy, N. \& Karodia, A.M. 2016. Investigating the impact of medical malpractice litigation on healthcare delivery in Gauteng. Journal of Research and Development (JRND) 2(11), 149-192

30. Obi, P. 2014. Breaking News.......At last NMA call off strike. This Day Live. Retrieved at http://www.thisdaylive.com/articles/breaking_news_at_last_nma_calls_off_strike/187230/on 2/10/2016

31. OECD 2006. Summary records of a conference on financial education, India, 21-22

32. Oginski, G. 2012. Secrets of a New York medical malpractice and personal injury attorney. $2^{\text {nd }}$ Edition Pennsylvania: Word Association Publishers

33. Okechukwu, C.S. 2016. The bane of selling general insurance in Nigeria. International Journal of Social Studies 2(3), 130-149

34. Okojie, E. 1995. Professional medical negligence in Nigeria. www.nigerianlawguru.com>...pdf

35. Outreville, J.F. 1998. Theory and practice of insurance. New York: Springer Science Business Media. 
36. Pandit, M.S. \& Pandit, S. 2009. Medical negligence: Coverage of the profession, duties, thics, case law and enlightened defense - A case perspective. Indian Journal of Urology, 25(3) 372-378. doi:10.4103/0970-1591.56206

37. PWC 2015. Africa insurance trends: Strategic and emerging trends in insurance markets in Nigeria. www.pwc.com.ng/insurance

38. Sekaran, U. \& Bongie, R. 2016. Research methods for business: A skill-building approach. $7^{\text {th }}$ ed USA: John Wiley \& Sons limited

39. Suganya, G. 2017. A study on assessing insurance awareness in India. International Journal of Humanities and Social Science Invention, 6(7), 46-49.

40. Tomczyk, P., Doligalski, T. \& Zaborek, P. 2016. Does customer analysis affect firm performance? Quantitative evidence from the Polish insurance market. Journal of Business Research, 6(365), 47-61

41. Tooth, R. 2015. Analysis of demand for home and content insurance. Australia: Insurance Council of Australia 